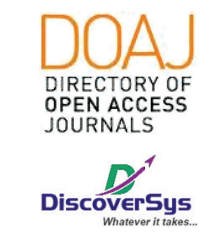

Published by DiscoverSys

\section{Korelasi negatif kuat kadar prolaktin plasma yang rendah terhadap derajat keparahan melasma}

\author{
Angela Sandi Tagaroi Rahasia, ${ }^{*}$ Anak Agung Gde Putra Wiraguna, \\ Luh Made Mas Rusyati
}

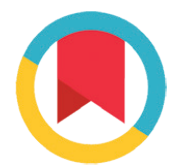

CrossMark

\title{
ABSTRACT
}

Background: Melasma is a chronic cutaneous hypermelanosis in areas exposed to sunlight. Hormonal factors are known to influence melanogenesis processes such as prolactin as a neuroendocrine modulator in skin epithelial growth and immune system. This study aims to prove the inverse relationship between plasma prolactin levels and the severity of melasma.

Methods: A cross-sectional study was carried out on 59 patients in the skin and genital olyclinic at Sanglah Hospital in Denpasar involving 46 subjects of melasma and 13 subjects who were not melasma who met the inclusion and exclusion criteria. Plasma prolactin levels were assessed by the Chemiluminescent microparticle immunoassay (CMIA) method. Data analysis was performed using SPSS ver. 23 software with a P-value $<0.05$ was considered statistically significant.
Results: Plasma prolactin levels in patients with melasma were significantly lower than non-melasma patients $(p<0.05)$. Patients with moderate and severe degrees of melasma had significantly lower plasma prolactin levels compared with mild degree of melasma $(p<0.05)$. Low plasma prolactin levels can increase the likelihood of melasma by 4.79 times (PR 4.79; $95 \% \mathrm{Cl}=0.94-$ $24.27 ; p<0.05)$. Low plasma prolactin levels were significantly strong negative correlated with melasma severity $(r=-0.820$; $\mathrm{p}<0.05)$.

Conclusion: There is a strong negative correlation of low plasma prolactin levels with the severity of melasma in patients with skin disorders at Sanglah General Hospital
Departemen Kulit dan Kelamin, Fakultas Kedokteran Universitas Udayana, RSUP Sanglah, Bali, Indonesia

*Korespondensi: Angela Sandi Tagaroi Rahasia, Departemen Kulit dan Kelamin, Fakultas Kedokteran Universitas Udayana, RSUP Sanglah, Bali, Indonesia angela.rahasia@yahoo.com

Received: 2018-09-17 Accepted: 2018-10-07 Published: 2019-04-01

Keywords: Melasma, Plasma Prolactin Levels, MASI Score

Cite This Article: Rahasia, A.S.T., Wiraguna, A.A.G.P., Rusyati, L.M.M. 2019. Korelasi negatif kuat kadar prolaktin plasma yang rendah terhadap derajat keparahan melasma. Intisari Sains Medis 10(1): 95-101. D0I: 10.1556/ism.v10i1.309

\section{ABSTRAK}

Latar Belakang: Melasma merupakan hipermelanosis kutaneus kronik pada area yang terpajan sinar matahari. Faktor hormonal diketahui berpengaruh dalam proses melanogenesis seperti prolaktin sebagai suatu modulator neuroendokrin pada pertumbuhan epitel kulit dan sistem imun kulit. Penelitian ini bertujuan membuktikan hubungan terbalik antara kadar prolaktin plasma dengan derajat keparahan melasma.

Metode: Penelitian dengan desain potong-lintang dilakukan terhadap 59 pasien di poliklinik kulit dan kelamin RSUP Sanglah Denpasar yang melibatkan 46 subyek melasma dan 13 subyek bukan melasma yang memenuhi kriteria inklusi dan eksklusi. Kadar prolaktin plasma diperiksa dengan metode Chemiluminescent microparticle immunoassay (CMIA). Data analisis dilakukan menggunakan piranti lunak SPSS ver. 23 dengan nilai $\mathrm{P}<0.05$ diketahui bermakna secara statistic.
Hasil: Kadar prolaktin plasma pada subyek melasma lebih rendah dibandingkan dengan subyek bukan melasma secara bermakna $(p<0,05)$. Subyek melasma derajat sedang dan derajat berat mempunyai kadar prolaktin plasma lebih rendah dibandingkan subyek melasma derajat ringan secara bermakna $(p<0,05)$. Kadar prolaktin plasma yang rendah dapat meningkatkan kemungkinan terjadinya melasma sebesar 4,79 kali (PR 4,79; Cl 95\% = 0,94-24,27; $\mathrm{p}<0,05)$. Kadar prolaktin plasma yang rendah berkorelasi negatif bermakna sangat kuat dengan derajat keparahan melasma ( $r=-$ $0,820 ; p<0,05)$.

Kesimpulan: Terdapat suatu korelasi negatif kuat kadar prolaktin plasma yang rendah terhadap derajat keparahan melasma pada pasien dengan permasalahan kulit di RSUP Sanglah.

Kata kunci: Melasma, Kadar Prolaktin Plasma, Skor MASI

Cite Pasal Ini: Rahasia, A.S.T., Wiraguna, A.A.G.P., Rusyati, L.M.M. 2019. Korelasi negatif kuat kadar prolaktin plasma yang rendah terhadap derajat keparahan melasma. Intisari Sains Medis 10(1): 95-101. D0I: 10.1556/ism.v10i1.309

\section{PENDAHULUAN}

Gangguan pigmentasi pada kulit merupakan keadaan dimana terjadinya perubahan warna pada kulit dimana dapat disebabkan oleh berbagai macam faktor baik internal maupun eksternal. Kelainan pigmentasi sendiri dapat dibagi menjadi dua berdasarkan morfologinya yaitu hipomelanosis 
dan hipermelanosis. Melasma merupakan gangguan manifestasi berupa hipermelanosis. ${ }^{1}$ Melasma dapat mengenai semua ras terutama penduduk yang tinggal di daerah tropis. Melasma terutama di jumpai pada wanita yakni pada hampir 90\% kasus dengan rentang usia terbanyak 30-50 tahun, meskipun didapat pula pada pria, serta lebih banyak mengenai orang yang memiliki tipe kulit berwarna lebih gelap, dan stigmanya sering dihubungkan dengan orang-orang berkultur Asia. ${ }^{2}$ Angka prevalensi melasma pada tahun 2004 di Rumah Sakit Umum Dr. Cipto Mangunkusumo Jakarta adalah sebesar 2,39\% dimana 97,93\% merupakan pasien wanita. Selain itu, penelitian retrospektif pada bagian Divisi kosmetik Rumah Sakit Umum Daerah Dr. Soetomo Surabaya tahun 2009-2011 menunjukkan bahwa angka prevalensi melasma pada pasien wanita sebesar 99,2\% dan pasien lakilaki $0,8 \% .^{3}$

Faktor hormonal diketahui memiliki peran yang penting dalam terjadinya melasma. Beberapa penelitian terdahulu telah menunjukkan bahwa terdapat beberapa hormon yang turut serta berpengaruh terhadap perkembangan melasma, diantaranya: estrogen, progesteron, tiroid, hingga prolactin. ${ }^{4-6}$ Aktivitas biologis prolaktin yang diketahui secara fisiologis berhubungan dengan terbentuknya melasma adalah melalui perannya secara tidak langsung terhadap sel keratinosit yang mempengaruhi juga PDZK1 (gene protein) dimana dapat terjadi peningkatan tirosinase ekspresi dan melanosome transfer ke keratinosit. Prolaktin dapat meningkatkan produksi kemokin CXCL9, 10, dan 11 yang diinduksi oleh IFN- $\gamma$ melalui aktivasi STAT1, nuclear factor- $\kappa \beta(\mathrm{NF}-\kappa \beta)$ dan interferon regulatory factor (IRF)1 melalui Janus kinase (JAK)2 dan Jalur MEK/ERK. Pengaruh dari berbagai macam sitokin proinflamasi yang dihasilkan dari prolaktin ini secara tidak langsung juga mempengaruhi Cutaneous-Endocrine Axis yakni dalam hal transportasi melanosome dari sel melanosit kepada sel keratinosit.7 Alhasil, hal ini akan berdampak pada proses pigmentasi kulit itu sendiri.

Meskipun demikian, peran dari hormon prolaktin terhadap terjadinya melasma belumlah menunjukkan hasil yang konsisten antara beberapa penelitian terdahulu. Studi yang dilakukan oleh Gopichandani K dkk dimana menunjukkan kadar hormon prolaktin tidak bermakna secara statistik terhadap kejadian melasma $(\mathrm{P}>0.05 ; r=$ 0.156). ${ }^{8}$ Disamping itu, studi yang dilakukan oleh Pérez dkk juga menemukan adanya nilai kadar prolaktin prolaktin yang normal pada 9 pasien melasma ketika dibandingkan dengan kelompok control. ${ }^{9}$ Akan tetapi terdapat hasil yang berbeda pada sebuah studi yang dilakukan oleh Hassan dkk dimana pengukuran kadar prolakin pasien melasma pada hari ke-9 dari siklus menstruasi menunjukkan adanya penurunan secara bermakna ketika dibandingkan dengan kelompok control. ${ }^{10}$ Oleh karena itu mereka berpendapat bahwa beberapa "lingkungan hormonal/Hormonal milieu" diperlukan untuk mempertahankan melasma, namun mereka tidak mengkhususkan peran pasti prolaktin dalam mempertahankan melasma.

Berkaitan dengan beberapa uraian yang telah dipaparkan diatas diketahui bahwa masih terdapat hubungan yang belum jelas antara kadar prolaktin dengan melasma. Beberapa penelitian menunjukkan tidak terdapat hubungan yang bermakna antara kadar prolaktin dengan kejadian melasma, namun studi lainnya menunjukkan kecenderungan penurunan kadar prolaktin pada pasien dengan melasma. Oleh karena adanya beberapa penelitian yang kontroversial tersebut, maka dilakukan penelitian ini untuk mengetahui korelasi antara kadar prolaktin dalam plasma darah dengan derajat keparahan melasma pada penderita melasma yang berkunjung ke Rumah Sakit Umum Pusat (RSUP) Sanglah Denpasar.

\section{METODE}

\section{Kriteria Responden}

Rancangan cross-sectional analitik yang dilakukan pada Poliklinik Penyakit Kulit dan Kelamin FK Unud/RS Sanglah Denpasar dilakukan pada bulan Mei-Juli 2018. Sampel penelitian terdiri dari 46 subjek melasma dan 13 subjek bukan melasma yang diambil dari populasi terjangkau menggunakan teknik consecutive sampling dimana telah memenuhi kriteria inklusi dan eksklusi penelitian. Kriteria inklusi pada penelitian ini meliputi pasien melasma, rentang usia 21-55 tahun, Jenis kelamin perempuan atau laki-laki, serta memiliki tipe kulit Fitzpatrick IV hingga VI.

\section{Pemeriksaan Melasma dan Prolaktin}

Diagnosis melasma ditegakkan berdasarkan gambaran klinis dan pemeriksaan penunjang berupa lampu Wood. Kedalaman lesi dapat ditentukan dengan lampu Wood, lesi epidermal akan tampak semakin jelas bila terkena sinar lampu Wood sedangkan lesi dermal akan tampak semakin tidak jelas, dan tipe campuran merupakan campuran dari keduanya. Sedangkan derajat keparahan melasma ditentukan berdasarkan nilai MASI yang dikembangkan oleh Kimbrough-Green dkk. Keparahan melasma pada masing-masing daerah (dahi, regio malar kanan, regio malar kiri, dan dagu) dinilai berdasarkan 3 variabel: persentase total area terlibat (A), tingkat kegelapan (D), dan homogenitas (H). Kemudian, kadar prolaktin pada penelitian ini diukur dari bahan sampel plasma 
yang diambil dari pembuluh darah vena subjek penelitian serta kemudian dikirim untuk diperiksa lebih lanjut pada laboratorium Prodia. Hasil pemeriksaan didapatkan sebagai data numerik dengan satuan nanogram per $\mathrm{ml}(\mathrm{ng} / \mathrm{ml})$.

\section{Analisis Data dan Etika Penelitian}

Data yang dikumpulkan diperiksa, dikode, diolah dan dianalisis menggunakan perangkat lunak komputer. Data ditampilkan dalam bentuk rata-rata, simpang baku, maupun persentase. Uji normalitas data dilakukan menggunakan uji KolmogorovSmirnov. Analisis bivariat dilakukan untuk mengukur prevalence ratio (PR) maupun interval kepercayaan (IK) 95\%. Uji statistik terhadap data dilakukan dengan program Statistical Package for Social Sciences (SPSS) versi 23.0. Protokol penelitian untuk Ethical Clearance dari Komisi Etik Penelitian Fakultas Kedokteran UNUD/ RSUP Sanglah Denpasar telah diberikan sebelum penelitian dilaksanakan (1973/UN14.2.2.VII.14/LP/2018)

\section{HASIL}

\section{Karakteristik Subyek Penelitian}

Berdasarkan kelompok umur, diketahui bahwa kelompok umur terbanyak adalah kelompok usia $>50-60$ tahun yakni sebanyak 15 orang $(32,6 \%)$. Pada subyek melasma didapatkan usia rerata adalah 45,17 $\pm 7,8$ tahun. Pada kelompok kontrol didapatkan kelompok umur 21-30 adalah yang terbanyak yakni sebanyak 9 orang $(69,2 \%)$. Pada subyek bukan melasma didapatkan rerata adalah $30,92 \pm 4,2$ tahun.

Berdasarkan distribusi lesi didapatkan pola melasma terbanyak adalah pola malar sebanyak 36 kasus (78,3\%), diikuti oleh pola sentrofasial sebanyak 10 kasus $(21,7 \%)$, dan tidak didapatkan pola mandibular pada subyek penelitian ini. Derajat keparahan melasma diukur berdasarkan skor MASI (Melasma Area and Severity Index) dengan nilai minimum 5 dan nilai maksimum 47. Sebanyak 16 subyek $(34,8 \%)$ termasuk dalam melasma derajat ringan (nilai MASI 0-16,9), 21 subyek $(45,7 \%)$ termasuk melasma derajat sedang (nilai MASI 17-32,9), dan 9 subyek (19,6\%) termasuk dalam melasma derajat berat (nilai MASI 33-48) (Tabel 1).

\section{Kadar Prolaktin Plasma Antara Subyek Melasma dengan Bukan Melasma}

Prolaktin plasma pada subyek melasma memiliki nilai tengah $6,48 \mathrm{ng} / \mathrm{mL}$ dengan interquartile range (IQR) 2.64. Pada subyek bukan melasma didapatkan nilai tengah 9,25 ng/mL dengan IQR 7.16. Karena kedua data tidak terdistribusi secara normal maka dilakukan uji non-parametrik Mann-Wihitney untuk membandingkan kadar prolaktin plasma pada kedua grup dan diapatkan nilai kemaknaan (p) sebesar $0.004(\mathrm{p}<0.05)$. Hal ini menunjukkan bahwa kadar Prolaktin plasma antara subyek melasma secara statistik signifikan lebih rendah dibandingkan pada subyek bukan melasma. Data ditampilkan pada Tabel 2.

\section{Perbandingan Kadar Prolaktin antara Melasma Derajat Ringan, Derajat Sedang, Derajat Berat}

Tabulasi silang dilakukan untuk melihat perbandingan kadar prolaktin plasma pada kelompok derajat melasma. Karena kadar prolaktin plasma pada kelompok melasma tidak terdistribusi secara normal, maka titik potong didasarkan pada median kadar prolaktin yaitu $6.48 \mathrm{ng} / \mathrm{mL}$ (CI 95\% 7,72$16,1)$ sehingga variabel diklasifikasikan menjadi 2 bagian yaitu kadar prolaktin $<6.48 \mathrm{ng} / \mathrm{mL}$ dan kadar prolaktin $>6.48 \mathrm{ng} / \mathrm{mL}$. Pada tabulasi silang dapat dilihat bahwa seluruh pasien dengan melasma derajat berat memiliki kadar prolaktin plasma $<6.48 \mathrm{ng} / \mathrm{mL}$. Dengan menggunakan uji chi-square, ditemukan nilai kemaknaan $\mathrm{p}<0,05$ yang berarti bahwa kadar prolaktin dan derajat melasma memiliki hubungan yang signifikan secara statistik, dimana semakin rendah kadar prolaktin plasma maka derajat melasma cenderung semakin tinggi. Data ditampilkan pada Tabel 2.

Gambar 1 menampilkan box plot yang menunjukkan nilai tengah kadar prolaktin pada subyek melasma berdasarkan derajat keparahan penyakit. Kadar prolaktin tertinggi pada subyek melasma derajat ringan adalah sebesar $8,43(6,06-22,63)$ $\mathrm{ng} / \mathrm{mL}$. Pada subyek melasma derajat sedang kadar prolaktin diketahui 6,18 $(4,78-7,81) \mathrm{ng} / \mathrm{mL}$. Sedangkan pada subyek melasma derajat berat kadar prolaktin diketahui 4,45 (4,13-5,42) ng/mL.

\section{Penurunan Kadar Prolaktin Plasma dapat Meningkatkan Kemungkinan Terjadinya Melasma}

Nilai Prevalence Ratio (PR) dapat dihitung dengan menggunakan rerata kadar prolaktin plasma yaitu $6.48 \mathrm{ng} / \mathrm{mL}$. Untuk mengetahui bahwa kadar prolaktin plasma dapat meningkatkan kemungkinan terjadinya melasma digunakan uji chi-square yang disajikan pada Table 3 .

Tabel 3. ini menunjukkan bahwa terdapat hubungan antara kadar prolaktin plasma dengan melasma. Kadar prolaktin plasma yang rendah dapat meningkatkan kemungkinan terjadinya melasma sebesar 4,79 kali (PR 4,79; CI 95\% = 0,9424,26; $\mathrm{p}<0,05)$ dibandingkan dengan kadar prolaktin plasma yang tinggi. 
Tabel 1 Gambaran karakteristik subyek dan variabel penelitian

\begin{tabular}{|c|c|c|c|}
\hline \multirow[b]{2}{*}{ Variabel } & \multicolumn{2}{|c|}{ Kelompok } & \multirow[b]{2}{*}{ Nilai-P } \\
\hline & $\begin{array}{l}\text { Melasma } \\
n=46(\%)\end{array}$ & $\begin{array}{c}\text { Tidak melasma } \\
n=13(\%)\end{array}$ & \\
\hline Umur (tahun) & $45,17 \pm 7,8$ & $30,92 \pm 4,2$ & \\
\hline $21-30$ & $1(2,2)$ & $9(69,2)$ & \\
\hline$>30-40$ & $13(28,3)$ & $3(23,1)$ & \\
\hline$>40-50$ & $17(37)$ & $1(7,7)$ & \\
\hline$>50-60$ & $15(32,6)$ & - & \\
\hline \multicolumn{4}{|l|}{ Jenis kelamin } \\
\hline Perempuan & $46(100)$ & $13(100)$ & \\
\hline Laki-laki & - & - & \\
\hline \multicolumn{4}{|l|}{ Pola melasma } \\
\hline Sentrofasial & $36(78,3)$ & - & \\
\hline Malar & $10(21,7)$ & - & 0,001 \\
\hline Mandibular & - & - & \\
\hline \multicolumn{4}{|c|}{ Derajat keparahan melasma } \\
\hline Ringan & $16(34,8)$ & - & \\
\hline Sedang & $21(45,7)$ & - & \\
\hline Berat & $9(19,6)$ & - & \\
\hline \multicolumn{4}{|c|}{ Paparan sinar matahari } \\
\hline$<3$ jam/hari & $24(52,2)$ & $13(100)$ & \\
\hline jam/hari & $22(47,8)$ & - & \\
\hline$>6 \mathrm{jam} / \mathrm{hari}$ & - & - & \\
\hline
\end{tabular}

Signifikansi $\mathrm{p}>0,05$

Tabel 2 Perbandingan kadar Prolaktin plasma antara subyek melasma dengan bukan melasma

\begin{tabular}{lccc}
\hline & \multicolumn{3}{c}{ Kelompok } \\
\cline { 2 - 3 } Variabel & $\begin{array}{c}\text { Melasma } \\
(\mathbf{n}=\mathbf{4 6})\end{array}$ & $\begin{array}{c}\text { Tidak melasma } \\
(\mathbf{n}=\mathbf{1 3})\end{array}$ & Nilai $\mathbf{P}$ \\
\hline $\begin{array}{l}\text { Prolaktin median } \\
(\mathrm{IQR})\end{array}$ & $6,48(2.64)$ & $9,25(7.16)$ & 0,004 \\
\hline
\end{tabular}

IQR: Interquartile Range; Signifikansi nilai $p<0,05$

Tabel 2 Kadar Prolaktin antara melasma derajat ringan, derajat sedang, dan derajat berat

\begin{tabular}{lcccc}
\hline & \multicolumn{3}{c}{ Kelompok melasma } \\
\cline { 2 - 4 } Variabel & $\begin{array}{c}\text { Derajat ringan } \\
(\mathbf{n = 1 9 )}\end{array}$ & $\begin{array}{c}\text { Derajat sedang } \\
(\mathbf{n = 2 0 )}\end{array}$ & $\begin{array}{c}\text { Derajat berat } \\
(\mathbf{n}=\mathbf{7})\end{array}$ & Nilai P \\
\hline $\begin{array}{l}\text { Kadar Prolaktin } \\
<6.48 \mathrm{ng} / \mathrm{mL}(\%)\end{array}$ & $3(15.8 \%)$ & $13(65 \%)$ & $7(100 \%)$ & 0,000 \\
$\begin{array}{l}\text { Kadar Prolaktin } \\
>6.48 \mathrm{ng} / \mathrm{mL}(\%)\end{array}$ & $16(84.2 \%)$ & $7(35 \%)$ & $0(0.0 \%)$ & \\
\hline
\end{tabular}

Signifikansi nilai $p<0,05$

\section{Korelasi Kadar Prolaktin dengan Derajat Keparahan Melasma berdasarkan Skor MASI (Melasma Area and Severity Index)}

Penelitian ini menunjukkan bahwa terdapat korelasi negatif sangat kuat dan secara statistik bermakna antara kadar Prolaktin plasma dengan derajat keparahan melasma yang diukur berdasarkan skor MASI $(\mathrm{r}=-0.820 ; p<0,000)$ (Tabel 4$)$. Pada grafik dapat dilihat bahwa semakin rendah kadar prolaktin, justru semakin tinggi skor MASI (Gambar 2).

\section{Analisis Regresi Linier Kadar Prolaktin Plasma terhadap Skor Melasma Area Severity Index}

Analisis regresi linier dilakukan untuk menguji pengaruh kadar Prolaktin plasma terhadap skor MASI dan didapatkan koefisien beta sebesar $-1,88$, koefisien determinasi 0,421, dan nilai $\mathrm{p}<0,05$. Pada penelitian ini didapatkan korelasi negatif yang sangat kuat antara Prolaktin plasma terhadap skor MASI, dengan menunjukan bahwa setiap penurunan $1 \mathrm{mIU} / \mathrm{L}$ Prolaktin plasma akan disertai peningkatan skor MASI sebesar 1,88. Koefisien determinasi $\left(R^{2}\right)$ 0,421 yang berarti kadar prolaktin plasma mempengaruhi $42,1 \%$ terhadap melasma (skor MASI).

\section{PEMBAHASAN}

Keseluruhan subyek berjenis kelamin wanita dengan umur termuda 27 tahun dan tertua 55 tahun (rerata 42,03 $\pm 9,3$ tahun). Hasil yang didapatkan dari studi ini dari segi umur lebih tua dibandingkan dengan studi - studi sebelumya, misalnya studi yang dilakukan oleh Bhattarai dkk yang meneliti pasien melasma yang dirawat di pusat perawatan tersier Nepal, dimana ditemukan distribusi usia pasien melasma pada kisaran usia 20-56 tahun dengan rerata usia $30.83+7.45$ tahun. ${ }^{11}$ Akan tetapi, penelitian lain yang sama-sama dilakukan di Indonesia menunjukkan bahwa rerata usia yang ditemukan pada pasien melasma di klinik Rejuva Skin \& Beauty Surabaya adalah $43.4+6.1$ tahun dengan dominasi kelompok umur 46-55 tahun yaitu sebesar $40 \%$ dimana hal ini hampir serupa dengan hasil penelitian ini. ${ }^{12-14}$

Seluruh subyek pada penelitian ini adalah berjenis kelamin perempuan. Hal ini serupa dengan penelitian-penelitian yang telah dilakukan sebelumnya. Secara umum, epidemiologi melasma memang lebih sering terjadi pada perempuan dibandingkan dengan laki-laki. Melasma 
Tabel 3 Penurunan Kadar Prolaktin Plasma dapat Meningkatkan Kemungkinan Terjadinya Melasma (Prevalence ratio)

\begin{tabular}{|c|c|c|c|c|c|c|c|}
\hline & & \multicolumn{2}{|c|}{ Melasma } & \multirow[b]{2}{*}{ PR } & \multicolumn{2}{|c|}{ Cl 95\% } & \multirow[b]{2}{*}{$\mathbf{P}$} \\
\hline \multicolumn{2}{|c|}{ Parameter } & Ya & Tidak & & $\min$ & $\max$ & \\
\hline \multirow{2}{*}{$\begin{array}{l}\text { Kadar } \\
\text { Prolaktin }\end{array}$} & Rendah & 23 & 2 & 4,79 & 0,94 & 24,26 & $0,043^{*}$ \\
\hline & Normal & 24 & 10 & & & & \\
\hline
\end{tabular}

Signifikansi $\mathrm{p}<0,05 ; \mathrm{PR}=$ Prevalence ratio

Tabel 4 Korelasi antara Prolaktin dengan derajat keparahan melasma

\begin{tabular}{lcc}
\hline & \multicolumn{2}{c}{ Skor MASI } \\
\cline { 2 - 3 } Variabel & $\mathbf{r}$ & Nilai $\mathbf{p}$ \\
\hline Kadar Prolaktin & -0.820 & 0,000 \\
\hline
\end{tabular}

$\mathrm{r}$ : koefisien korelasi dari Spearman

Tabel 5 Hasil uji regresi linier pengaruh kadar Prolaktin plasma dengan skor MASI

\begin{tabular}{llr}
\hline & Regresi linier kadar Prolaktin plasma dengan skor MASI \\
\hline 1 & Koefisien Beta & $-1,88$ \\
2 & Koefisien determinasi $\left(\mathrm{R}^{2}\right)$ & 0,421 \\
3 & Kemaknaan $(\mathrm{p})$ & 0,000 \\
\hline
\end{tabular}

Signifikansi nilai $p<0,05$

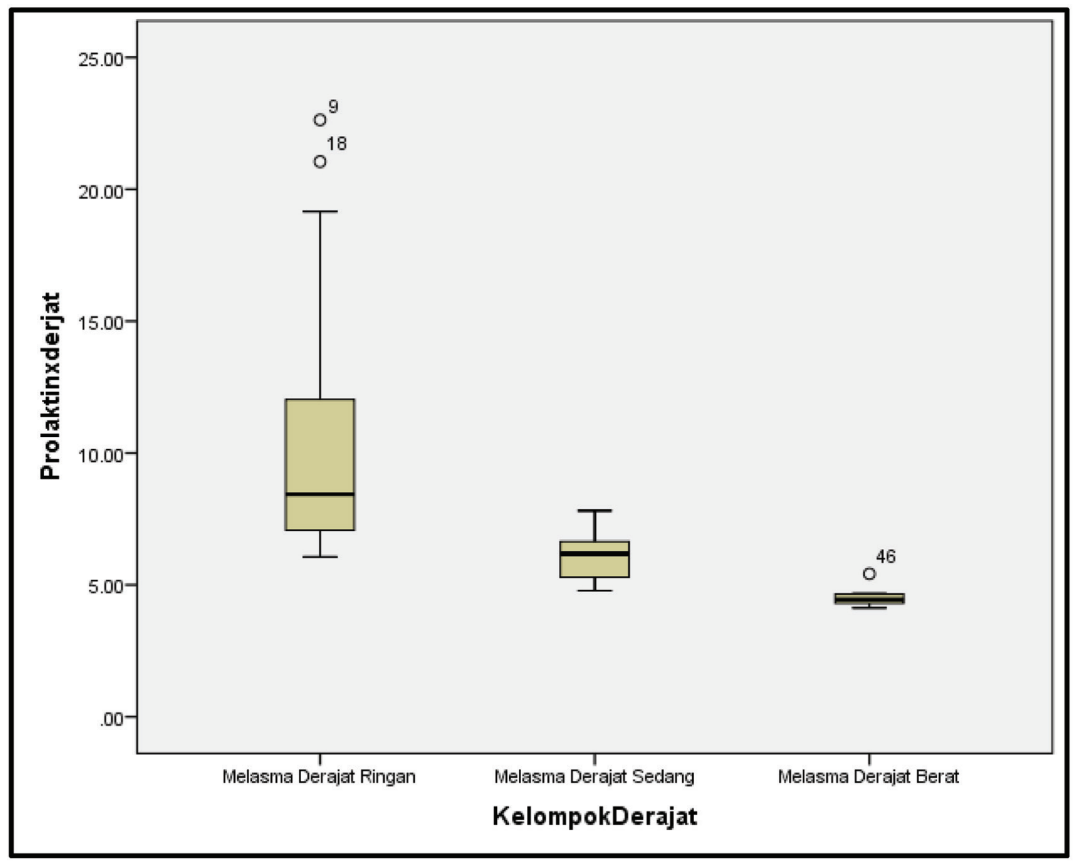

Gambar 1 Box Plot perbandingan kadar prolaktin pada melasma derajat ringan, sedang, dan berat

lebih sering ditemukan pada wanita (90\%) yang dihubungkan dengan faktor hormonal, namun melasma dapat juga terjadi pada laki - laki. ${ }^{15}$ Studi yang dilakukan Praharsini dkk menemukan bahwa hanya terdapat $8.7 \%$ sampel melasma yang berjenis kelamin pria, hal ini dikarekanan prevalensi global melasma pada laki-laki dibandingkan dengan perempuan adalah 1:2 dan berperannya faktor hormonal menyebabkan perempuan lebih rentan terkena melasma. Selain itu, perempuan juga cenderung lebih menyadari dan khawatir mengenai kondisi kulitnya sehingga lebih sering mencari pengobatan dengan berkunjung ke klinik. ${ }^{16}$ Pada pria, sekresi prolaktin stabil sejak anak-anak, dewasa dan lanjut usia, namun pada wanita terjadi peningkatan sekresi prolaktin pada masa reproduksi dibandingkan setelah menopause. ${ }^{17}$

Pada penelitian ini pada 46 subjek dengan melasma, ditemukan 24 subyek (52.2\%) terpapar sinar matahari dibawah 3 jam perhari, dan 22 subyek $(47,8 \%)$ terpapar matahari sebanyak 3 hingga 6 jam tiap hari, sedangkan pada subjek tanpa melasma seluruhnya terkena paparan sinar matahari di bawah 3 jam setiap harinya. Paparan sinar ultraviolet adalah salah satu faktor pemicu terjadinya melasma. Sinar ultraviolet, dapat menstimulasi melanogenesis, dan menyebabkan melasma apabila terdapat faktor predisposisi genetik atau perubahan hormon. ${ }^{18}$ Hasil serupa ditunjukkan oleh studi yang dilakukan oleh Martin dkk dimana ditemukan $63 \%$ pasien melasma memiliki riwayat paparan sinar matahari leboh dari 2 jam dalam sehari. ${ }^{19-21}$ Sinar UV, inflamasi pada keratinosit merangsang pembentukan plasminogen activator (PA) yang kemudian merangsang melanogenesis. PA dapat menstimulasi pembentukan plasmin yang dapat merangsang pembentukan fibroblast growth factor (FGF) yang kemudian dapat merangsang melanogenesis melalui melanocyte growth factor. Plasmin dapat pula memicu pelepasan asam arachidonat dan prostaglandin yang juga menstimulasi melanogenesis. ${ }^{22}$

Hubungan antara melasma dan radiasi UV diasumsikan berdasarkan efek dan mekanisme kerja radiasi UV pada transfer melanogenesis / melanosome. Melanogenesis yang diinduksi oleh UV dimediasi oleh efek langsung dari UV foton pada DNA dan membran melanosit. UV iradiasi melepaskan diacyl glycerol (DAG) dan asam arakidonat dari melanosit membran. ${ }^{23}$ Keratinosit juga mensekresikan nitrit oksida (NO) sebagai respons terhadap radiasi UV, memainkan peran penting dalam melanogenesis yang diinduksi oleh UV jalur siklik guanosin monofosfat. Peran dari NO dalam patogenesis melasma didasarkan pada pengamatan peningkatan ekspresi sintesis NO yang diinduksi dalam hiperpigmentasi kulit lesi melasma. ${ }^{23}$

Terdapat 3 pola distribusi utama lesi melasma, yaitu sentrofasial yang meliputi daerah dahi, pipi, hidung, bibir atas dan dagu; malar yang meliputi pipi dan hidung; serta mandibular yang meliputi ramus mandibula dan sekitarnya. ${ }^{24}$ Pada penelitian 


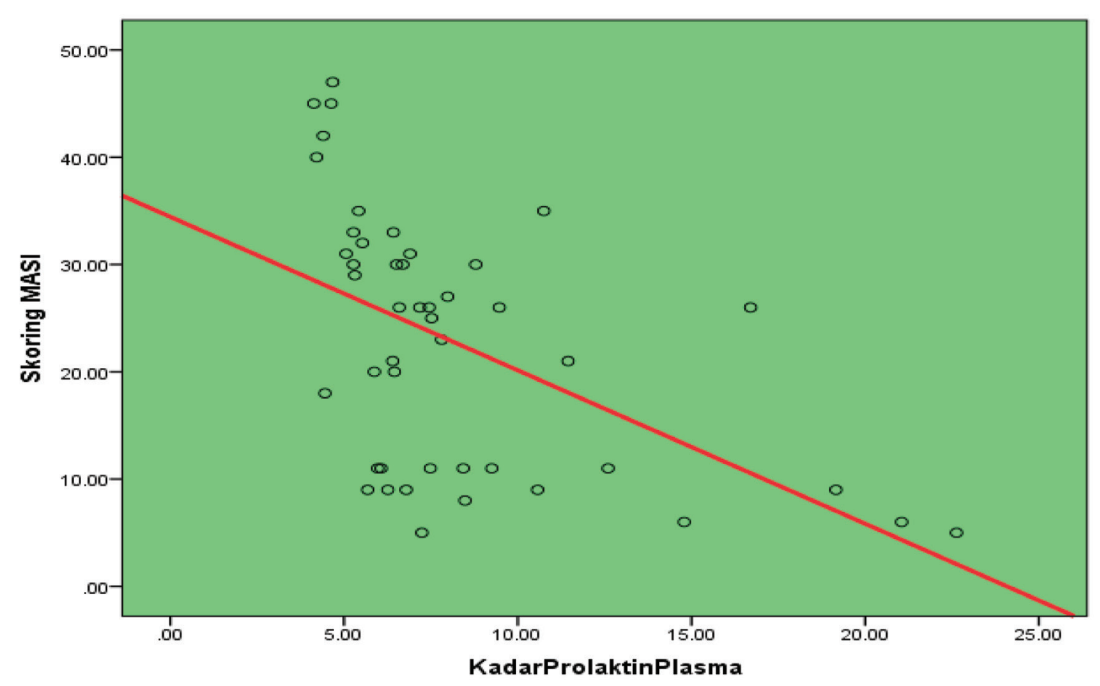

Gambar 2 Scatter Plot korelasi kadar Prolaktin plasma dengan skor MASI

ini didapatkan pola melasma terbanyak pada subyek adalah pola malar $(78,3 \%)$, diikuti oleh pola sentrofasial $(21,7 \%)$ dan tidak didapatkan adanya pola mandibular pada penelitian ini. Hasil ini hampir serupa dengan penelitian yang dilakukan Djajapranata dimana ditemukan bahwa distribusi lokasi melasma terbanyak adalah pada daerah malar yaitu sebesar $72.7 \%{ }^{13}$ Akan tetapi hasil ini berbeda dengan temuan dari studi yang dilakukan Tamega dkk dimana didapatkan $69.2 \%$ pasien melasma memiliki pola distribusi sentrofasial sedangkan $30.8 \%$ Penyebabnya perbedaan hasil ini mungkin dapat disebabkan karena banyak responden yang menggunakan pelindung kepala agar terhindar dari paparan sinar matahari sehingga bagian wajah sentral lebih terlindungi. ${ }^{13}$

Derajat keparahan melasma dinyatakan dalam skor Melasma Area Severity Index (MASI) yang terbagi menjadi 3 tingkat, ringan bila skor MASI 0-16,9; sedang bila skor MASI 17-32,9; dan berat bila skor MASI 33-48. Pada penelitian ini didapatkan sebanyak 16 subyek $(34,8 \%)$ memiliki derajat keparahan melasma ringan, 21 subyek (45.7\%) dengan melasma derajat keparahan sedang (skor MASI 17-32,9), dan melasma derajat keparahan berat (skor MASI 33-48) sebanyak 9 subyek (19,6\%). Hasil ini serupa dengan temuan dari Bhattarai dkk dmana kebanyakan pasien melasma memiliki skor MASI 20-30 (47.1\%). ${ }^{25}$ Skor MASI diduga dapat dipengaruhi oleh berbagai faktor salah satunya adalah faktor hormonal.

Pada penelitian ini didapatkan perbedaan rerata kadar Prolaktin plasma pada subyek melasma dibandingkan subyek bukan melasma. Rerata kadar Prolaktin plasma pada subyek melasma dibandinkan dengan subyek bukan melasma $(\mathrm{p}<0.05)$. Hal ini menunjukkan bahwa terdapat perbedaan yang bermakna kadar Prolaktin plasma antara subyek melasma dibandingkan pada subyek bukan melasma, dimana pada subjek melasma kadar prolaktinnya lebih rendah dibandingkan dengan yang tidak melasma. Hal ini berbeda dengan studi yang dilakukan oleh Mahmood dkk, dimana mereka menemukan bahwa prolaktin tidak memiliki peran dalam terjadinya melasma karena dari total 138 pasien, hanya 4 pasien yang mengalami peningkatan kadar prolaktin sedangkan yang lainnya kadar prolaktinnya tetap normal, namun prolaktin yang menurun diperkirakan memiliki hubungan dengan terjadinya melasma meskipun belum dapat dibuktikan dalam studi tersebut. ${ }^{26}$ Sedangkan pada studi yang dilakukan Hassan dkk, ditemukan penurunan signifikan pada serum prolaktin pasien melasma dibandingkan kontrol hanya pada hari ke 9 dalam siklus menstruasi wanita. ${ }^{27}$ Hasil yang berbeda juga ditunjukkan dari studi yang dilakukan Gopichandani dkk dimana rerata prolaktin pada kasus adalah $15.74+14.58$ sedangkan pada kontrol adalah $12.05+4.65$ akan tetapi perbedaan ini tidak memiliki makna secara statistic. ${ }^{8}$

Dari berbagai literatur sebelumnya, diperkirakan peran prolaktin pada kulit adalah menstimulasi proliferasi keratinosit dan berbagai aktivitas proinflamasi yaitu produksi IFN- $\gamma$ oleh limfosit T dan merangsang angiogenesis. ${ }^{7}$ Selain itu diperkirakan hormone prolaktin dapat menurunkan estrogen. Hormon seks seperti estrogen dan progesteron diketahui bepengaruh dalam regulasi sintesis melanin. Sebuah studi yang dilakukan oleh Natale dkk, menemukan bahwa setelah 4 hari memberikan eksposure $25 \mathrm{nM}$ estrogen terhadap melanosit manusia, melanin meningkat secara signifikan sebanyak 208\%. Diduga bahwa peran estrogen terhadap pembentukan pigmen melanin berjalan melalui jalur sinaling cAMP dan ikatan dengan membrane protein G pada reseptor GPER dan PAQ7. Hasil ini menjadikan dasar bahwa estrogen yang meningkat dapat meningkatkan kejadian melasma melalui peningkatkan produksi melanin. ${ }^{28}$ Peningkatan ekspresi estrogen juga diketahui dapat meningkatkan ekspresi dari PDZ Domain Protein Kidney 1 (PDZK1), dimana peningkatan PDZK1 dua kali lipat dari normal dapat menyebabkan hiperpigmentasi pada kulit. PDZK1 yang merupakan gen protein yang memiliki korelasi dengan melanogenesis. ${ }^{29}$

Pada penelitian ini kadar Prolaktin plasma pada subyek melasma berbeda menurut derajat keparahannya. Pada melasma derajat ringan didapatkan nilai median 8.43 dengan IQR 5.7; sedangkan pada subyek melasma derajat sedang memiliki nilai median 6,18 dengan IQR 1.39, dan subyek melasma derajat berat memiliki nilai median 4,45 dengan IQR 0.46 dengan nilai $\mathrm{p}=0,000(\mathrm{p}<0,05)$. Hal ini 
menunjukkan adanya perbedaan yang signifikan secara statistik antara kadar Prolaktin plasma dengan derajat keparahan melasma, yang berarti semakin tinggi derajat melasma maka nilai kadar prolaktin justru semakin menurun.

Hasil penelitian ini juga menunjukkan terdapat korelasi negatif kuat bermakna antara kadar prolaktin dengan derajat keparahan melasma berdasarkan nilai skor MASI. Selain itu, analisis regresi linier dilakukan untuk menguji pengaruh kadar Prolaktin plasma terhadap skor MASI dan didapatkan koefisien beta sebesar $-1,88$, koefisien determinasi $42,1 \%$, dan nilai $\mathrm{p}=0,000$, yang berarti bahwa setiap penurunan $1 \mathrm{mIU} / \mathrm{L}$ Prolaktin plasma akan disertai peningkatan skor MASI sebesar 0,649. Hasil ini hampir serupa dengan studi yang dilakukan Gopichandani dkk dimana ditemukan adanya hubungan berbanding terbalik anatara kadar prolaktin dengan skor MASI dimana peningkatan kadar prolaktin akan menurunkan MASI sebesar 0.26 kali namun hasil ini tidak signifikan secara statistik. ${ }^{8}$ Studi yang melihat efek dari prolaktin terhadap MASI masih belum memadai, namun dengan asumsi bahwa semakin rendah kadar prolaktin maka akan semakin tinggi melanogenesis yang dipicu oleh peningkatan kadar estrogen, maka dapat di tarik kesimpulan bahwa semakin rendah kadar prolaktin keparahan melasma akan semakin tinggi yang dapat dilihat melalui peningkatan skor MASI.

\section{SIMPULAN}

Hasil penelitian ini menunjukkan bahwa terdapat suatu korelasi negatif kuat kadar prolaktin plasma yang rendah terhadap kejadian melasma maupun derajat keparahannya pada pasien di RSUP Sanglah Denpasar

\section{DAFTAR PUSTAKA}

1. Bleehen SS, Anstey AV.Disorder of skin colour: pathogenesis of disorders of melanin pigmentation, melasma. In: Burns T, Breathnach S, Cox N, Griffiths C, editor. Rook's textbook of dermatology. 7. Massachusetts: Blackwell; 2004; 39:13-14

2. Roberts WE. Melasma. In: Kelly AP, Taylor SC, editor. Dermatology for skin of colour. New York: McGraw-Hill. 2009; 332-6.

3. Febrianti T, Sudharmono A, Rata IGAK, Bernadette I. Epidemiologi Melasma di Poliklinik Departemen Ilmu Kesehatan Kulit dan Kelamin RS. Dr. Cipto mangunkusumo Jakarta Tahun. Perdoski. 2004. Tersedia pada: perdoski.org/index.php/public/information/mdvi-detail-content/86. [Diakses 17 Juni 2017]

4. Diven DG, Gwinup G, Newton RC. The thyroid. Dermatol Clin. 1989; 7:547- 558

5. Dogra A, Dua A, Singh P. Thyroid and skin. Indian Journal of Dermatology. 2006; 51(2): 96-9.

6. Mahmood K, Nadeem M, Aman S, Hameed A, Kazmi AH Role of Estrogen, Progesterone, and Prolactin in the Etopathogenesis of Melasma in Females. Journal of Pakistan Association of Dermatologist. 2011; 21(4):241-247
7. Langan EA, Foitzik-Lau K, Goffin V, Ramot Y, Paus R. Prolactin: An Emerging Force along the CutaneousEndocrine Axis. Trends Endocrinol Metab. 2010; 21:569-77.

8. Gopichandani K, Arora P, Garga U, Bhardwaj M, Sharma N, Gautam RK. Hormonal profile of melasma in Indian females. Pigment Int. 2015; 2: 85-90.

9. Pérez M, Sánchez JL, Aguiló F. Endocrinologic profile of patients with idiopathic melasma. J Invest Dermatol. 1983; 81:543-5.

10. Hassan I, Kaur I, Sialy R, Dash RJ. Hormonal milieu in the maintenance of melasma in fertile women. J Dermatol. $1998 ; 25: 510-2$

11. Bhattarai S, Pradhan K, Sharma S, Rajouria EA. Clinical patterns and epidemiological characteristics of melasma in a tertiary care hospital of Nepal. Pigmentary Disorder Society. 2017; 4(1):35-38

12. Tamega Ade A, Miot LD, Bonfietti C, Gige TC, Marques ME, Miot HA. Clinical patterns and epidemiological characteristic of facial melisma in Brazillian women. J Eur Acad Dermatol Venereol. 2013; 27(2):151-6

13. Djajapranata K. Profil Melasma pada Perempuan Usia 16-65 Tahun Menggunakan Lampu Wood di Rejuva Skin \& Beauty Surabaya. Surabaya: Repositori Universitas Katolik Widya Mandala. 2016

14. Kaur S, Kaur J, Sharma S, Sharma M, Mahajan A, Singh A. A Clinico-dermatocospic study of 100 cases of melisma in a tertiary care hospital. Int J Res Dermatol. 2018; 4(1):41-45

15. Muller I, Rees DA. Melasma and Endocrine Disorders. Pigmentary Disorders. 2014; S1:001

16. Praharsini I, Suryawati N, Dewi H. Skor kualitas hidup dermatologi berkolerasi positif dengan melisma area and severity indez. Intisari Sains Medis. 2017; 8(2):189-192

17. Roelfsema F, Pijl H, Keenan DM, Veldhuis JD. Prolactin Secretion in Healthy Adults Determined by Gender, Age and Body Mass Index. Plos One. 2012; 7(2): 1-10.

18. Handel AC, Miot LDB, Miot HA. Melasma: a clinical and epidemiological review. An Bras Dermatol. 2014; 89(5): 771-82.

19. Martin M, Hamdullah A, Priya S. Unveiling factors behind melasma: an Observational Study. IAIM. 2017; 4(11):85-89

20. Sonthalia S, Sarkar R. Etiopathogenesis of Melasma. Pigmentary Disorders Society. 2015; 2(1):21-27

21. Videira IF, Magina S, Moura DFF. Mechanisms regulating melanogenesis. An Bras Dermand. 2013; 88(1): 76-83.

22. Tse TW, Hui E. Tranexamid Acid: an Important Adjuvant in the Treatment of Melasma. Journal of Cosmetic Dermatology. 2013; 12:57-66

23. Lee AY. An Update Review of melasma Pathogenesis. South Korea. Dermatologica Sinica. 2014; 32:233-39.

24. Laperee H, Boone B, Schepper SD et al. Hypomelanoses and Hypermelanoses. In: Fitzpatrick TB, Wolff K, editor. Dermatology in general medicine. New York: McGraw Hill. 2008; (7):622-640

25. Bhattarai S, Pradhan K, Sharma S, Rajouria EA. Clinical patterns and epidemiological characteristics of melasma in a tertiary care hospital of Nepal. Pigment Int 2017;4:35-8

26. Mahmood K, Nadeem M, Aman S, Hameed A, Kazmi AH. Role of estrogen, progesterone, and prolactin in the etiopathogenesis of melasma in females. Journal of Pakistan Association of Dermatologists. 2011; 21(4):241-247.

27. Hassan I, Kaur I, Sialy R, Dash RJ. Hormonal milieu in the maintenance of melasma in fertile women. J Dermatol. 1998; 25(8):510-2.

28. Natale C, Dupperet E, Zhang J, Sadeghi R, Dahal A, Brien K et al. Sex Steroids regulate skin pigmentation through nonclassical membrane bound receptor. eLife. 2016; 1-15

29. Lee AY. Recent progress in melasma pathogenesis. Pigment Cell Melanoma Res 2015; 28:648-60

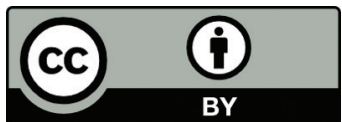

This work is licensed under a Creative Commons Attribution 